\title{
Impact of rapid eye movement sleep behavior disorder and autonomic disorders on Parkinson's disease: a review
}

\author{
Impacto do transtorno comportamental do sono REM e doenças autonômicas na doença \\ de Parkinson: uma revisão
}

Pérola de OLIVEIRA' Francisco CARDOSO²

\begin{abstract}
Parkinson's disease (PD) has heterogeneous clinical manifestations and prognoses. It is accompanied by a group of motor and non-motor symptoms ranging from independence to total disability, limiting work and personal care activities. Currently, disease subtype markers for informing prognosis remain elusive. However, some studies have reported an association between rapid eye movement (REM) sleep behavior disorder (RBD) and faster motor and non-motor symptom progression, including autonomic dysfunction and cognitive decline. Moreover, since autonomic dysfunction has been described in idiopathic forms of RBD, and they share some central regulatory pathways, it remains unclear whether they have a primary association or if they are more severe in patients with PD and RBD, and thus are a disease subtype marker. This article aimed at critically reviewing the literature on the controversies about the prevalence of RBD in PD, the higher incidence of PD non-motor symptoms associated with RBD, the evidence of faster motor worsening in parkinsonian patients with this parasomnia, and the main pathophysiological hypotheses that support these findings.
\end{abstract}

Keywords: Parkinson Disease; REM Sleep Behavior Disorder; Autonomic Nervous System Diseases; Pathology; Epidemiology.

RESUMO

A doença de Parkinson (DP) apresenta variadas manifestações clínicas e distintos prognósticos. É caracterizada por um conjunto de sintomas motores e não motores que podem variar desde um quadro de independência até a completa incapacidade laborativa e de cuidados pessoais. Até o momento, não está claro quais seriam os marcadores de subtipos da doença que poderiam alertar para formas de prognóstico. Porém existem alguns estudos que mostram que a presença do transtorno comportamental do sono REM pode estar associada à progressão mais rápida dos sintomas motores e não motores, como disfunção autonômica e declínio cognitivo. Questiona-se ainda se a disautonomia está primariamente associada ao transtorno do sono REM, já que são relatadas nas formas idiopáticas deste transtorno de sono e compartilham alguns núcleos reguladores centrais. Ou se são mais graves nos pacientes com diagnóstico de DP e transtorno comportamental do sono REM, marcando assim um subtipo da doença. Esta revisão teve como objetivo revisar criticamente os principais estudos publicados envolvendo as controvérsias sobre a prevalência do transtorno comportamental do sono REM na DP, a maior incidência de sintomas não motores da DP associados ao transtorno do sono REM, as evidências de piora motora mais rápida nos pacientes parkinsonianos que apresentam este transtorno do sono e as principais hipóteses fisiopatológicas que justificam esses achados.

Palavras-chave: Doença de Parkinson; Transtorno do Comportamento do Sono REM; Doenças do Sistema Nervoso Autônomo; Patologia; Epidemiologia.

\section{INTRODUCTION}

Parkinson's disease (PD) has heterogeneous clinical manifestations and prognoses. It is classified based on the clinical presentation of motor symptoms and is often categorized as either tremor or non-tremor dominant subtypes. The latter is characterized by predominant akinesia/rigidity, gait disturbance, or postural instability. These clinical presentations impact the prognosis and could contribute towards the better elucidation of PD mechanisms ${ }^{1}$.

Several studies have addressed the presence and prevalence of non-motor symptoms in PD and their association

${ }^{1}$ Rede SARAH de Hospitais de Reabilitação, Departamento de Neurologia, Brasília DF, Brazil.

${ }^{2}$ Universidade Federal de Minas Gerais, Unidade de Distúrbios do Movimento, Serviço de Neurologia, Departamento de Clínica Médica, Belo Horizonte MG, Brazil. Pérola de OLIVEIRA (ID https://orcid.org/0000-0003-1824-5578; Francisco CARDOSO (iD https://orcid.org/0000-0003-0808-0116

Correspondence: Francisco Cardoso; E-mail:fecardosoc@gmail.com

Conflict of interest: PO has no conflict of interest to declare. FC is President-Elect of the International Parkinson's Disease and Movement Disorders Society. Authors' contributions: PO: participated in the planning, execution, and preparation of the manuscript. FC: advisor and supervisor of this review.

Received on April 23, 2020; Received in its final form on June 14, 2020; Accepted on June 25, 2020. 
with motor disease subtypes and prognosis. These studies could provide a better understanding of the disease subtypes, severity markers, and associated risk factors. Among the non-motor symptoms, rapid eye movement (REM) sleep behavior disorder (RBD) and autonomic dysfunction indicate a more severe and disabling form of the disease $\mathrm{e}^{2,3,4,5}$. It remains unclear whether RBD is a PD subtype marker and whether it is associated with a higher prevalence of other non-motor symptoms, including cognitive decline and autonomic dysfunction. The latter could be primarily associated with RBD or more prevalent and severe in patients with PD and $\mathrm{RBD}^{6,7}$.

This review aimed to assess the impact of RBD on PD, the controversies about its prevalence, other non-motor symptoms that seem to be associated with RBD, especially autonomic dysfunctions, thus defining a PD subtype, and the pathophysiological hypotheses that support these findings.

\section{RAPID EYE MOVEMENT SLEEP BEHAVIOR DISORDER}

PD patients with different etiologies have a high prevalence of sleep disorders ( $>70 \%)$. They include nighttime sleep disorders and daytime sleepiness, with the most common being insomnia, RBD, and restless legs syndrome ${ }^{8}$.

$\mathrm{RBD}$ is characterized by behaviors resulting from acting out dreams involving complex non-stereotyped movements, such as light gestures, punches, kicks, and even violent movements, potentially leading to injury of the patient as well as their bed partner?

According to the International Classification of Sleep Disorders, the four criteria for RBD diagnosis ${ }^{10,11}$ are:

- Repeated episodes of sleep-related vocalization and/or complex motor behavior;

- Behaviors documented by polysomnography during REM sleep or presumed to occur during REM sleep based on clinical history;

- REM sleep without atonia on polysomnography;

- Sleep disturbance cannot be explained by another sleep disorder, mental illness, medication use, or substance use.

A definitive RBD diagnosis requires polysomnography. Typical polysomnography findings include REM sleep without atonia, sustained increase in muscle tone on chin electromyography, and excessive transient muscle activity in the chin or limbs.

RBD is classified as probable when abnormal REM sleep behavior is reported without documentation by polysomnography. Further, it is classified as subclinical upon finding sustained electrophysiological changes on polysomnography with no compatible history. Not all patients develop classic $\mathrm{RBD}^{11}$. Patients with RBD are alert and oriented upon waking up from sleep.
Given the lengthy nature of polysomnography and its limited availability, questionnaires have been developed for RBD screening and to support a probable RBD diagnosis. The RBD screening questionnaire, which is the most widely used questionnaire, was validated in 2007. It is a 10-item self-report questionnaire with yes or no answers and a maximum score of 13 points. The Hong Kong version of the RBD questionnaire ${ }^{10}$ was validated in 2010 and consists of 13 self-assessment questions that include an "I do not know" option among the answers. It assesses the presence and severity of RBD symptoms. The Innsbruck questionnaire is simpler since it comprises nine items - seven specific for RBD and two (questions four and nine) assessing other sleep disorders. The REM Sleep Behavior Disorder Single-Question Screen was validated in 2012. It has a single question: "Have you ever been told, or suspected yourself, that you seem to 'act out your dreams' while asleep ( for example, punching, flailing your arms in the air, making running movements, etc.)?" with the possible answers being "yes" or "no"10. The Mayo Sleep Questionnaire is not specific for RBD and contains 16 questions, with one being directed at RBD. In case of a positive answer, RBD-specific sub-items should be subsequently completed ${ }^{10}$.

RBD symptoms usually start in late adulthood, with the mean age at diagnosis being $60-70$ years. Most cases involve a gradual and progressive symptom onset, with a delay of several years between symptom onset and diagnosis. The prevalence of RBD in the general population and among older adults is approximately $0.5-10$ and $2 \%$, respectively. In addition, some studies have shown that the condition is more prevalent in men, while others have reported no sex-based difference ${ }^{11}$. RBD can be classified as idiopathic (iRBD) when it occurs in the absence of any neurological disorders or other possible causes. Contrastingly, it is classified as secondary in case of neurodegenerative diseases, in particular, those associated with synucleinopathies, including PD, dementia with Lewy bodies, and multiple system atrophy.

In some patients, RBD occurs months or even decades before the development of motor impairment associated with neurodegenerative diseases, highlighting the need for the correct classification of iRBD. Physiological motor activity suppression during REM sleep happens in several neuronal circuits that begin in the pons and terminate on spinal cord motor neurons. A normal atonia during REM sleep results in quiet motor activity and supports sleeprelated memory consolidation. Muscle atonia during REM sleep causes RBD and has an apparent association with dysfunction of the pontine nuclei of the reticular formation. However, the exact mechanism underlying this REM sleep disorder remains unclear and has been reported to involve several brainstem structures, including the locus coeruleus, subcoeruleus, periaqueductal gray matter, ventral mesopontine junction, pedunculopontine tegmental 
nucleus, peri-locus coeruleus area at the pons, and bulbar nuclei (Figure 1).

A proposed hypothesis for the underlying mechanism of RBD is the specific degeneration of a population of glutamatergic neurons located in the sublaterodorsal nucleus of the pons, which are responsible for muscle atonia. Another possibility is the injury of glycinergic and GABAergic premotor neurons of the ventromedial hypothalamic nucleus. Some studies have reported the presence of Lewy bodies in the midbrain and pons areas involved in REM sleep atonia ${ }^{12}$.

\section{IDIOPATHIC RAPID EYE MOVEMENT SLEEP BEHAVIOR DISORDER}

iRBD, which occurs without neurodegenerative disease, was first described in 1986, with similar phenomenological reports being presented in the 1970s. It is characterized by central nervous system (CNS) dysfunction during sleep and wakefulness with cortical activity impairment, neuropsychological changes, and autonomic dysfunction ${ }^{13}$.

According to several studies, patients with iRBD present abnormalities in heart rate variability, myocardial scintigraphy, and cardiovascular autonomic reflex tests (Table 1) 6,7,14,15,16,17,18. Moreover, previous studies have suggested that the type and severity of these autonomic dysfunctions could predict the development of RBD-associated neurodegenerative diseases ${ }^{19}$.

\section{RAPID EYE MOVEMENT SLEEP BEHAVIOR DISORDER IN PARKINSON'S DISEASE}

The risk of patients with iRBD developing PD or dementia is estimated to be 20 to $45 \%$ higher during the first five
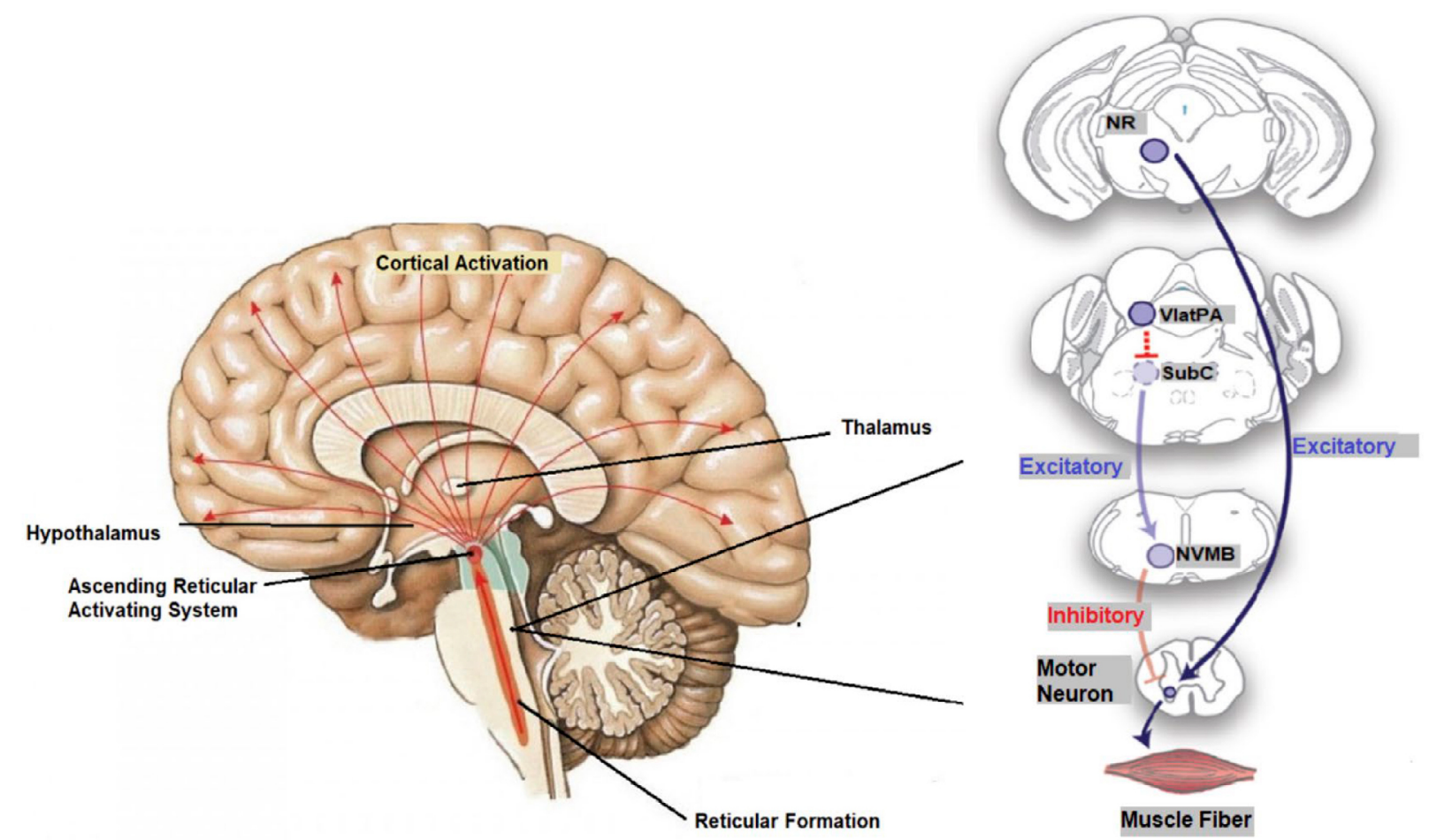

Source: adapted from Fraigne et al.12.

NR: red nucleus; VlatPA: ventrolateral periaqueductal gray matter; SubC: subcoeruleus; NVMB: ventromedial nucleus of the bulb.

Figure 1. Areas involved in rapid eye movement sleep behavioral disorder.

Table 1. Findings on idiopathic rapid eye movement sleep behavior disorder.

\begin{tabular}{lccccc}
\hline Author & Year & Country & iRBD $(n)$ & RBD diagnostic method & Findings \\
\hline $\begin{array}{l}\text { Postuma } \\
\text { et al. }{ }^{4}\end{array}$ & 2010 & Canada & 99 & Polysomnography & $\begin{array}{r}\text { Patients with RBD showed cardiac autonomic } \\
\text { dysfunction in both those who developed and did not } \\
\text { develop neurodegenerative disease. }\end{array}$ \\
$\begin{array}{l}\text { Frauscher } \\
\text { et al. }{ }^{6}\end{array}$ & 2012 & Austria & 15 & Polysomnography & Presence of autonomic dysfunction in patients with iRBD. \\
\hline
\end{tabular}


Table 1. Continuation.

\begin{tabular}{lccccc}
\hline Author & Year & Country & iRBD $(\mathrm{n})$ & RBD diagnostic method & \multicolumn{1}{c}{ Findings } \\
\hline $\begin{array}{l}\text { Sorensen } \\
\text { et al. }\end{array}$ & 2013 & Denmark & 11 & Polysomnography & $\begin{array}{c}\text { Patients with RBD had attenuated } \\
\text { sympathetic activity. }\end{array}$ \\
$\begin{array}{l}\text { Ferini-Strambi } \\
\text { et al. }\end{array}$ & 2014 & Multicenter & 318 & Polysomnography & $\begin{array}{r}\text { Patients with iRBD had more gastrointestinal, } \\
\text { cardiovascular, and urinary problems. }\end{array}$ \\
$\begin{array}{l}\text { Lee } \\
\text { et al. }\end{array}$ & 2015 & Korea & 17 & Polysomnography & $\begin{array}{l}\text { iRBD was associated with autonomic dysfunction; } \\
\text { predominantly, adrenergic and cardiovagal functions. }\end{array}$ \\
$\begin{array}{l}\text { Aguirre-Mardones } \\
\text { et al. }\end{array}$ & 2015 & Spain & 44 & Polysomnography & iRBD was associated with hyposmia and constipation. \\
$\begin{array}{l}\text { Bedard } \\
\text { et al. }\end{array}$ & 2019 & Canada & 5 & Polysomnography & $\begin{array}{l}\text { Specific marker on positron emission } \\
\text { tomography showed brain cholinergic } \\
\text { alterations in patients with iRBD. }\end{array}$ \\
\hline
\end{tabular}

RBD: rapid eye movement (REM) sleep behavior disorder; iRBD: idiopathic RBD.

years of the parasomnia. The risk further increases over time, with $>80 \%$ of men being affected after approximately three decades of RBD progression ${ }^{11,20}$. A significant number of PD patients are affected by RBD; however, studies have reported varying values ranging from 15 to $>70 \%^{8,21,22}$. RBD may precede the onset of PD motor symptoms or appear with the progression of the disease, being more frequent and presenting more severe symptoms in advanced PD cases ${ }^{22}$. As shown in Table 2, most studies have assessed the clinical prevalence of RBD in PD patients; yet, few studies employed polysomnography $y^{1,5,8,23,24,25,26,27,28}$.

Zhang et al. ${ }^{22}$ conducted a meta-analysis and metaregression study on the prevalence of RBD in PD patients. They analyzed 28 studies published between 2010 and 2016 with a total of 8,689 PD patients. Less than half of these studies used polysomnography for RBD diagnosis, and the RBD prevalence ranged from 19.2 to $69.8 \%$. In 2017, another Chinese group carried out a meta-analysis of RBD prevalence in patients with early-onset PD. They included eight studies with 2,462 PD patients and found a mean prevalence of $23.6 \%$ (range: $4.3-69.4 \%$ ). Only one of the included studies used polysomnography for RBD diagnosis ${ }^{29}$. These meta-analyses indicated a high heterogeneity among the evaluated studies ${ }^{22}$, which could have resulted from the different methodologies for RBD diagnosis, with some studies using questionnaires and others using polysomnography. Further, the studies that only used the clinical features of RBD employed different questionnaires with distinct sensitivities and specificities. Moreover, the diagnostic efficacy of the most frequently used questionnaires has not been compared. Studies on RBD prevalence also used heterogeneous populations with different ethnicities, ages, and PD duration, with RBD being more prevalent in older adults and in more advanced PD stages ${ }^{21}$. RBD has recurrent symptoms; however, the patient may experience no symptoms for months after a period of intense symptom manifestation. Finally, most studies on RBD prevalence were cross-sectional, which can cause confusion and limit causality inferences. Therefore, despite numerous relevant studies, the actual prevalence of RBD in PD patients remains unknown and can only be estimated.

RBD in PD patients does not necessarily lead to disability but causes sleep disruption for the patient or bed partner, who may occasionally suffer involuntary physical aggression?. RBD appears to be associated with faster motor symptom progression and increased non-motor symptoms, including cognitive decline, psychiatric changes, and autonomic dysfunction. A study conducted in California and published in $2019^{30}$ assessed the presence of RBD in 776 PD patients. Based on the predominant motor symptom, they were classified into the following three clinical subtypes: postural instability and gait dysfunction, tremor dominant, or indeterminate. Patients were evaluated between 2001 and 2007 and reassessed between 2011 and 2017. The total RBD prevalence was $21 \%$. According to the Unified Parkinson's Disease Rating Scale score, patients with the postural instability and gait dysfunction subtype and RBD presented faster motor worsening. RBD patients progressed twice as fast to a score below the Mini-Mental State Examination cut-off point. As shown in Table 3, previous studies have identified an association between RBD and other non-motor symptoms of $\mathrm{PD}^{2,3,4,5,51,3}$ $1,32,33,34,35,36,37,38,39,40$. These recent studies indicate that RBD is a marker of a PD subtype with more frequent and severe motor and non-motor symptoms, as well as a poor prognosis. The proposal to classify RBD as a symptom of PD or other synucleinopathies further supports the hypothesis that RBD is a PD subtype marker.

Based on the PD model proposed by Braak et al. ${ }^{41}$, presymptomatic PD stages are characterized by the deposition of Lewy bodies in the dorsal pons, bulb, and olfactory nucleus. This explains why RBD precedes PD motor symptoms in some cases; nevertheless, it does not explain why many PD patients do not present RBD. Histopathological changes have been reported in patients with iRBD who did not clinically present neurological disorders. These changes included the presence of Lewy bodies in the brainstem in one 
Table 2. Prevalence of rapid eye movement sleep behavior disorder in Parkinson disease patients.

\begin{tabular}{|c|c|c|c|c|c|c|}
\hline Author & Year & Country & Total of PD patients & Diagnostic method & \multicolumn{2}{|c|}{ PD prevalence (\%) } \\
\hline Mahajan et al. ${ }^{5}$ & 2014 & USA & 418 & RBDSQ & \multicolumn{2}{|c|}{27.0} \\
\hline Munhoz et al. ${ }^{23}$ & 2014 & Brazil & 100 & ICSD-RBD & \multicolumn{2}{|c|}{58.0} \\
\hline Kim et al. ${ }^{24}$ & 2014 & Korea & 202 & ICSD-RBD & \multicolumn{2}{|c|}{57.4} \\
\hline Aygun et al.? & 2014 & Turkey & 104 & ICSD-RBD & $\begin{array}{c}N T \\
45.2\end{array}$ & $\begin{array}{c}T \\
54.8\end{array}$ \\
\hline Janković et al. ${ }^{8}$ & 2015 & Serbia & 97 & $\mathrm{RBDQ}-\mathrm{HK}$ & \multicolumn{2}{|c|}{15.5} \\
\hline $\begin{array}{l}\text { Alatriste-Booth } \\
\text { et al. }{ }^{25}\end{array}$ & 2015 & Brazil & 120 & Polysomnography & \multicolumn{2}{|c|}{35.1} \\
\hline Swallow et al. ${ }^{26}$ & 2016 & UK & 1,719 & RBDSQ & \multicolumn{2}{|c|}{43.3} \\
\hline Chahine et al. ${ }^{27}$ & 2016 & Multicenter & 423 & RBDSQ & \multicolumn{2}{|c|}{25.5} \\
\hline Suzuki et al. ${ }^{28}$ & 2017 & Multicenter & 436 & RBDSQ & \multicolumn{2}{|c|}{35.1} \\
\hline
\end{tabular}

RBD: rapid eye movement (REM) sleep behavior disorder; PD: Parkinson's disease; ICSD-RBD: minimum criteria for RBD according to the International Classification of Sleep Disorders; NT and T: non-tremor and tremor forms of Parkinson's disease; RBDQ-HK: RBD questionnaire-Hong Kong; RBDSQ: RBD screening questionnaire.

Table 3. Findings on the presence of rapid eye movement sleep behavior disorder in Parkinson disease patients.

\begin{tabular}{|c|c|c|c|c|c|c|}
\hline Author & Year & Country & $\begin{array}{l}\text { Total number } \\
\text { of PD patients }\end{array}$ & $\begin{array}{c}\text { RBD } \\
\text { (\% of total) }\end{array}$ & $\begin{array}{l}\text { Findings related to } \\
\text { PD motor symptoms }\end{array}$ & $\begin{array}{c}\text { Findings related to } \\
\text { PD non-motor symptoms }\end{array}$ \\
\hline $\begin{array}{l}\text { Postuma } \\
\text { et al. }^{31}\end{array}$ & 2011 & Canada & 53 & 60 & & $\begin{array}{l}\text { Cardiac autonomic denervation was } \\
\text { not associated with PD; rather, it was } \\
\text { associated with RBD. }\end{array}$ \\
\hline $\begin{array}{l}\text { Kim } \\
\text { et al. }{ }^{21}\end{array}$ & 2014 & Review & 4,089 & $20-72$ & & $\begin{array}{l}\text { RBD was associated with } \\
\text { hallucinations and dementia. }\end{array}$ \\
\hline $\begin{array}{l}\text { Mahajan } \\
\text { et al. }{ }^{5}\end{array}$ & 2014 & USA & 418 & 27 & $\begin{array}{l}\text { Patients with RBD were } 1.66 \\
\text { times more likely to present } \\
\text { worse motor symptoms. }\end{array}$ & $\begin{array}{l}\text { No depression differences between } \\
\text { patients with and without RBD. }\end{array}$ \\
\hline $\begin{array}{l}\text { Fantini } \\
\text { et al. }{ }^{32}\end{array}$ & 2015 & Multicenter & 216 & 53.0 & & $\begin{array}{c}\text { RBD was associated with an } \\
\text { increased risk of developing impulse } \\
\text { control disorders. }\end{array}$ \\
\hline $\begin{array}{l}\text { Cui } \\
\text { et al. }{ }^{33}\end{array}$ & 2017 & China & 403 & & & $\begin{array}{c}\text { RBD was a risk factor for anxiety } \\
\text { development (OR: } 1.029 \text { and p-value: } \\
0.037) \text {. }\end{array}$ \\
\hline $\begin{array}{l}\text { Liu } \\
\text { et al. }{ }^{4}\end{array}$ & 2017 & China & 141 & 21.3 & & $\begin{array}{c}\text { Patients with RBD had } \\
\text { more anxiety, depression, } \\
\text { constipation, hallucinations, and } \\
\text { a higher prevalence of orthostatic } \\
\text { hypotension. }\end{array}$ \\
\hline $\begin{array}{l}\text { Jozwiak } \\
\text { et al. }{ }^{34}\end{array}$ & 2017 & Canada & 93 & 56.9 & & $\begin{array}{c}\text { RBD was associated with greater } \\
\text { cognitive impairment and a higher } \\
\text { diagnosis frequency of mild cognitive } \\
\text { impairment. }\end{array}$ \\
\hline $\begin{array}{l}\text { Pagano } \\
\text { et al. }{ }^{2}\end{array}$ & 2018 & Multicenter & 421 & 37.5 & $\begin{array}{l}\text { RBD was associated } \\
\text { with a faster progression of } \\
\text { PD motor symptoms. }\end{array}$ & $\begin{array}{l}\text { RBD was associated with a greater } \\
\text { risk of cognitive decline and a higher } \\
\text { number of non-motor symptoms } \\
\text { associated with PD, including } \\
\text { hallucinations, pain, fatigue, } \\
\text { constipation, and urinary problems. }\end{array}$ \\
\hline $\begin{array}{l}\text { Kang } \\
\text { et al. }^{.35}\end{array}$ & 2013 & $\begin{array}{l}\text { Systematic } \\
\text { review }\end{array}$ & & & $\begin{array}{l}\text { Higher frequency of } \\
\text { RBD in the predominant } \\
\text { non-tremor PD phenotype. }\end{array}$ & $\begin{array}{c}\text { RBD was a risk factor for the } \\
\text { development of dementia and } \\
\text { hallucinations. }\end{array}$ \\
\hline $\begin{array}{l}\text { Kim } \\
\text { et al. }{ }^{36}\end{array}$ & 2018 & $\begin{array}{l}\text { Systematic } \\
\text { review }\end{array}$ & & & & $\begin{array}{c}\text { RBD in PD patients was associated } \\
\text { with greater disease severity and } \\
\text { increased mortality risk; further, the } \\
\text { authors suggested that RBD could } \\
\text { be a PD subtype marker. }\end{array}$ \\
\hline
\end{tabular}




\begin{tabular}{|c|c|c|c|c|c|c|}
\hline Author & Year & Country & $\begin{array}{l}\text { Total number } \\
\text { of PD patients }\end{array}$ & $\begin{array}{c}\text { RBD } \\
\text { (\% of total) }\end{array}$ & $\begin{array}{l}\text { Findings related to } \\
\text { PD motor symptoms }\end{array}$ & $\begin{array}{l}\text { Findings related to } \\
\text { PD non-motor symptoms }\end{array}$ \\
\hline $\begin{array}{l}\text { Liu } \\
\text { et al. }{ }^{37}\end{array}$ & 2019 & China & 158 & 19.6 & & $\begin{array}{l}\text { RBD was associated with } \\
\text { cognitive decline, other sleep } \\
\text { disorders, and anxiety. }\end{array}$ \\
\hline $\begin{array}{l}\text { Banks } \\
\text { et al. }^{38}\end{array}$ & 2019 & USA & 100 & & & $\begin{array}{c}\text { RBD was associated with gait motor } \\
\text { complications. }\end{array}$ \\
\hline $\begin{array}{l}\text { Baig } \\
\text { et al. }\end{array}$ & 2019 & UK & $\begin{array}{l}921 \text { (in the first } \\
\text { assessment) }\end{array}$ & & & $\begin{array}{l}\text { RBD was not associated with } \\
\text { an increased risk of developing } \\
\text { impulse control disorders. }\end{array}$ \\
\hline $\begin{array}{l}\text { Bargiotas } \\
\text { et al. }\end{array}$ & 2019 & Switzerland & 64 & 40.0 & & $\begin{array}{l}\text { RBD was associated with } \\
\text { apathy and increased depressive } \\
\text { symptom severity. }\end{array}$ \\
\hline $\begin{array}{l}\text { Pilotto } \\
\text { et al. }{ }^{40}\end{array}$ & 2019 & $\begin{array}{l}\text { Systematic } \\
\text { review }\end{array}$ & & & & $\begin{array}{l}\text { Patients with PD and RBD had an } \\
\text { increased risk of cognitive decline. } \\
\text { The authors proposed the existence } \\
\text { of a malignant PD phenotype } \\
\text { associated with RBD and orthostatic } \\
\text { hypotension, which could be } \\
\text { characterized by faster progression } \\
\text { of cognitive decline and } \\
\text { postural instability. }\end{array}$ \\
\hline
\end{tabular}

RBD: rapid eye movement (REM) sleep behavior disorder; PD: Parkinson's disease; OR: Odds Ratio.

patient and decreased monoaminergic neurons in the locus coeruleus and substantia nigra in another ${ }^{20}$.

A Spanish cohort study published in $2013^{42}$ assessed 44 patients with iRBD, of whom four remained disease-free until the end of the follow-up period. However, all four patients presented striatal abnormalities in the dopamine transporter in the neuroimaging examination, one showed transcranial ultrasonography abnormalities, and two had abnormalities in the olfactory test. Therefore, the iRBD concept remains controversial, and the use of the term "idiopathic" does not seem to be very appropriate. Alternative terms, such as cryptogenic RBD and isolated RBD, have been suggested to indicate RBD stages without other symptoms. Other authors have proposed that RBD is a symptom of alpha-synucleinopathy and not an isolated entity ${ }^{42}$.

\section{AUTONOMIC DYSFUNCTION}

Autonomic dysfunction or dysautonomia refers to impairment of the autonomic nervous system resulting from many different factors and diseases. Autonomic dysfunction usually manifests as more than one symptom. The most common autonomic dysfunction in PD patients is cardiovascular dysfunction with an abnormal vasovagal response, which can lead to syncope. Other common manifestations are orthostatic hypotension, constipation, neurogenic bladder, and sexual dysfunction.

Several brain areas modulate the activity of the autonomic nervous system, including the left amygdala, insula, periaqueductal gray matter, and cingulate cortex ${ }^{43}$. These areas are distributed across the forebrain and brainstem (Figure 2).

\section{IDIOPATHIC RAPID EYE MOVEMENT SLEEP BEHAVIOR DISORDER-ASSOCIATED AUTONOMIC DYSFUNCTION}

Although sleep is not regulated by the autonomic nervous system, some CNS areas regulate both systems. Therefore, sleep and autonomic system interactions might occur and can be descriptively separated into the three situations mentioned below.

First, autonomic dysfunction and sleep impairments might be induced by pathologies, including synucleinopathies with neurodegeneration of brainstem nuclei, which is involved in RBD pathogenesis and degeneration of central and peripheral autonomic regions. Second, the failure of sleep-related cardiorespiratory control mechanisms could cause or aggravate autonomic dysfunction, which might explain the high prevalence of nocturnal cardiac arrhythmia in patients with obstructive sleep apnea. Third, autonomic dysfunction could cause or aggravate a sleep disorder, as seen in familial dysautonomia. Nonetheless, the underlying pathophysiology is complex.

Autonomic cells in the hypothalamus and brainstem (Figure 3$)^{44}$ are closely associated with cells that regulate the sleep-wake cycle. Sleep is promoted by neurons in the ventrolateral preoptic nucleus of the thalamus, which secretes 

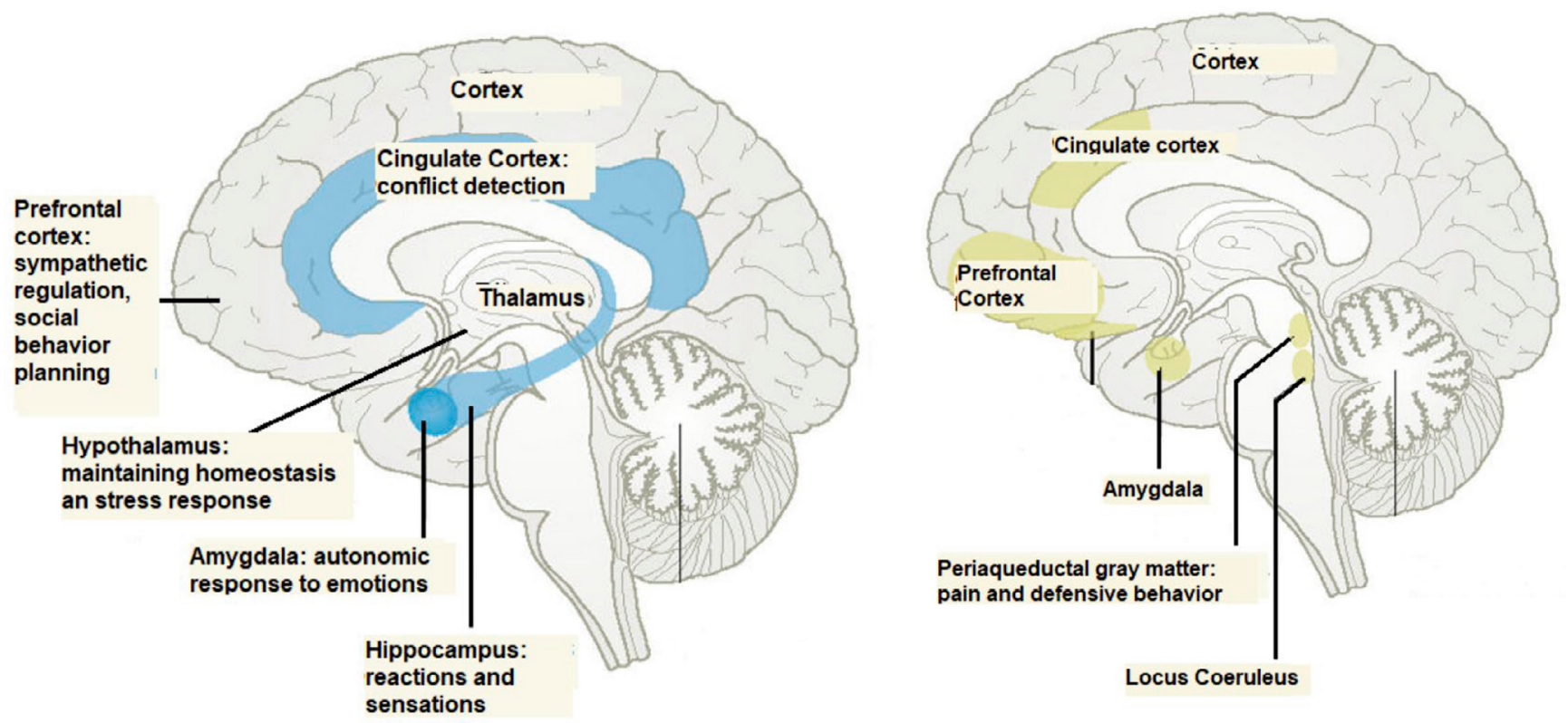

Source: adapted from Fenster et al. 44 .

Figure 2. Areas of the autonomic nervous system.

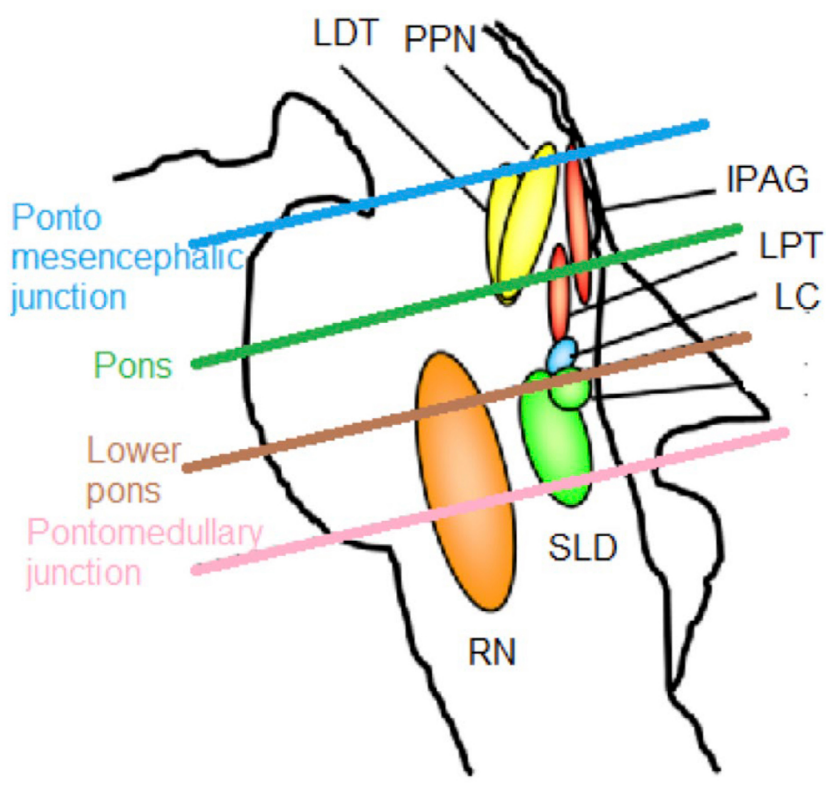

Source: adapted from Boeve et al.11.

LDT: laterodorsal tegmental nucleus; PPN: pedunculopontine nucleus; IPAG: periaqueductal gray matter; LPT: laterodorsal pons; LC: locus coeruleus; SLD: sublaterodorsal nucleus; RN: raphe nuclei.

Figure 3. Approximate location of important areas involved in rapid eye movement sleep behavioral disorder control and central autonomic modulation.

gamma-aminobutyric acid (GABA) and galanin neuropeptide. On the other hand, wakefulness is regulated by cholinergic and monoaminergic pathways. All these neurons are important for RBD. Monoaminergic pathways originate from the brainstem and send projections to the hypothalamus and cortex. The hypothalamus has glutaminergic and hypocretinsecreting neurons that project to all monoaminergic nuclei and are fundamental to maintain the waking conscious state. Hypocretin-secreting neurons are important in autonomic control and send projections to various regulatory centers of the autonomic nervous system, including the solitary tract nucleus and periaqueductal gray matter ${ }^{45}$. The lateral part of the bulb contains autonomic afferent and efferent pathways, which act on respiratory control during sleep and are associated with the pontine nuclei. Table 1 presents autonomic dysfunctions clinically associated with iRBD.

\section{AUTONOMIC DYSFUNCTION IN PARKINSON'S DISEASE}

The prevalence of autonomic symptoms in PD patients ranges from 14 to $80 \%$. This variability could be mainly attributed to differences in diagnostic methodology and the autonomic disorder assessed across studies. Further, several studies enrolled heterogeneous populations, while others did not use validated questionnaires ${ }^{46}$.

Regarding the non-motor symptoms of PD, dysautonomia, including orthostatic hypotension, constipation, sialorrhea, as well as urinary and sexual dysfunction, frequently occurs at all disease stages. However, they are more common in more advanced PD stages and significantly worsen the quality of life and impair social life.

Orthostatic hypotension has a significant impact on the quality of life, as well as morbidity and mortality, in PD patients. It is characterized by a $20 \mathrm{mmHg}$ decrease in systolic pressure and/or a $10 \mathrm{mmHg}$ decrease in diastolic pressure when the patient goes from a dorsal decubitus to a standing position ${ }^{45}$. Its clinical manifestations are diverse and 
nonspecific and include dizziness, vertigo, blurred vision, in addition to more serious complications, such as syncope and falls. Its prevalence in PD patients ranges from 30 to $60 \%{ }^{47}$. Orthostatic hypotension can be caused by autonomic dysfunction or other conditions, including hypovolemia, physical deconditioning, and medication use. Early diagnosis of orthostatic hypotension is essential to allow the provision of behavior guidance, reassessment of medication use, and prevention of serious consequences.

Constipation is characterized by colonic and anorectal symptoms and occurs up to two decades prior to motor symptoms of PD. PD patients present with reduced intestinal motility; moreover, there can be involvement of the entire gastrointestinal tract. Approximately $50-80 \%$ of PD patients have constipation, with about $20 \%$ of them presenting constipation before the onset of motor symptoms ${ }^{48}$. Constipation leads to functional impairment and psychosocial distress, which negatively affects the quality of life of PD patients.

Sialorrhea is characterized by excessive salivation and the inability to retain saliva within the mouth. Consequently, the patient might drool or aspirate saliva, which could even result in aspiration pneumonia. The prevalence of sialorrhea in PD patients varies from 10 to $84 \%{ }^{49}$ and is more frequent in case of ineffective medication.

Urinary tract symptoms have been recognized as nonmotor complications of PD since their description by James Parkinson in 1817. They are classified as irritative, obstructive, or mixed. The most common irritative symptoms in PD patients include nocturia and frequent and urgent urination. The prevalence of urinary problems in PD patients is up to $86 \%^{46}$, with nocturia being the most prevalent symptom followed by frequent and urgent urination.
Sexual function is a complex process dependent on the body's mechanical function and emotional health. Sexual dysfunction is common in PD patients and has been associated with depressive mood disorders. It is more prevalent among young male PD patients. The most common symptoms are erectile dysfunction and premature ejaculation. Erectile dysfunction has been reported in 50 to $79 \%$ of PD patients ${ }^{50}$. The most frequent complaints of female PD patients are vaginal discomfort, lack of lubrication, and sexual dissatisfaction. Further, motor symptoms of PD, including rigidity and bradykinesia, could impair sexual activity. Clinical symptoms of autonomic dysfunctions are often subjective, difficult to diagnose, and affected by confounding factors, such as comorbidities and medication use.

For early and accurate diagnosis, autonomic reactivity tests assist in identifying autonomic dysfunctions, quantifying the deficit severity, and determining the distribution and location of the autonomic injury. Several tests assess autonomic function, including cholinergic, cardiovagal, and adrenergic sympathetic reflex autonomic responses. However, these tests are not widely available and require expensive equipment and trained personnel.

\section{RELATIONSHIP BETWEEN RAPID EYE MOVEMENT SLEEP BEHAVIOR DISORDER AND AUTONOMIC DYSFUNCTION IN PARKINSON'S DISEASE}

RBD and autonomic dysfunction are correlated and common in PD patients (Table 4) ${ }^{19,51,52,53,54,55,56,57}$; however, whether autonomic dysfunction is more closely associated with RBD or $\mathrm{PD}$ itself remains unclear. There is recent but growing evidence

Table 4. Relationship between rapid eye movement sleep behavior disorder and autonomic dysfunction in Parkinson disease patients.

\begin{tabular}{|c|c|c|c|c|}
\hline Author & Year & Country & Sample & Findings \\
\hline $\begin{array}{l}\text { Nomura } \\
\text { et al. }{ }^{.1}\end{array}$ & 2013 & Japan & 82 PD patients & RBD was associated with orthostatic hypotension in PD patients. \\
\hline $\begin{array}{l}\text { Anang } \\
\text { et al. }{ }^{52}\end{array}$ & 2014 & Canada & 80 PD patients & $\begin{array}{l}\text { Cardiovascular autonomic dysfunction, RBD, gait disturbances, } \\
\text { and color discrimination ability were strong predictors of dementia } \\
\text { development in PD patients. }\end{array}$ \\
\hline $\begin{array}{l}\text { Kim } \\
\text { et al. }{ }^{53}\end{array}$ & 2016 & Korea & $\begin{array}{l}94 \text { PD patients; among } \\
\text { them, } 53 \text { had RBD }\end{array}$ & RBD in PD patients was associated with orthostatic hypotension. \\
\hline $\begin{array}{l}\text { Jin } \\
\text { et al. }{ }^{54}\end{array}$ & 2017 & Review & & $\begin{array}{l}\text { The authors suggested an association of autonomic dysfunctions } \\
\text { with RBD; moreover, this association could be a PD sign. However, they } \\
\text { emphasize the importance of further studies to prove this hypothesis. }\end{array}$ \\
\hline $\begin{array}{l}\text { Kim } \\
\text { et al. }{ }^{55}\end{array}$ & 2017 & Korea & 160 PD patients & $\begin{array}{c}\text { Patients with PD and low MIBG* uptake had a higher prevalence of } \\
\text { RBD, orthostatic hypotension, constipation, and cognitive decline } \\
\text { compared to those with normal uptake. }\end{array}$ \\
\hline $\begin{array}{l}\text { Fereshtehnejad } \\
\text { et al. }{ }^{56}\end{array}$ & 2017 & Review & & $\begin{array}{l}\text { Patients with PD associated with RBD and autonomic dysfunction } \\
\text { presented faster disease progression with more prominent motor } \\
\text { symptoms in the early PD stages. }\end{array}$ \\
\hline
\end{tabular}


Table 4. Continuation.

\begin{tabular}{|c|c|c|c|c|}
\hline Author & Year & Country & Sample & Findings \\
\hline $\begin{array}{l}\text { Al-Qassabi } \\
\text { et al. }{ }^{57}\end{array}$ & 2018 & Canada & $\begin{array}{l}150 \text { patients ( } 49 \text { with } \\
\text { iRBD, } 40 \text { with PD, } 20 \text { with } \\
\text { atypical parkinsonism, } \\
\text { and } 41 \text { controls) }\end{array}$ & $\begin{array}{c}\text { Patients with PD and concomitant RBD had significantly lower } \\
\text { skin sweat measurements than those with PD without RBD and } \\
\text { controls. This finding suggests a between-subgroup difference in the } \\
\text { peripheral alpha-synuclein deposition. }\end{array}$ \\
\hline $\begin{array}{l}\text { Zitser } \\
\text { et al. }{ }^{19}\end{array}$ & 2019 & Review & & $\begin{array}{l}\text { Autonomic symptoms were common in patients with RBD and } \\
\text { reported in up to } 94 \% \text { of patients. The presence and severity of } \\
\text { autonomic dysfunction symptoms in patients with RBD were } \\
\text { associated with the risk of progression to PD. } \\
\text { Moreover, it suggests an association of autonomic dysfunctions and } \\
\text { RBD with a malignant PD subtype. }\end{array}$ \\
\hline
\end{tabular}

RBD: rapid eye movement (REM) sleep behavior disorder; PD: Parkinson's disease; iRBD: idiopathic RBD; MIBG: metaiodobenzylguanidine, assessed through myocardial scintigraphy.

on the correlation of some non-motor symptoms with RBD as a risk factor for iRBD progression to PD. This could indicate that autonomic dysfunctions associated with RBD might be a preclinical PD marker ${ }^{54}$. Previous studies have revealed a significant impact of PD non-motor symptoms on the quality of life, including depression, cognitive decline, and sleep disorders. Studies have even reported that non-motor symptoms have a greater impact on the quality of life than motor symptoms ${ }^{58}$.

The various clinical presentations of PD, associations between motor and non-motor symptoms, and prognoses support the hypothesis that PD subtypes could be classified according to the predominant phenotype, severity, and prognosis markers. These findings substantiate the PD subclassification based on the predominant motor symptom and the presence of non-motor symptoms indicative of a more severe disease form. The coexistence of RBD and autonomic dysfunctions is associated with the phenotypic conversion to PD, non-motor symptoms (e.g., cognitive decline), and faster progression of motor symptoms, collectively describing what previous studies have termed the malignant PD form ${ }^{19}$.

In PD, autonomic dysfunction is related to worse quality of life regardless of disease duration, cognitive decline, or motor symptom severity ${ }^{59}$. Evidence suggests an association of autonomic dysfunctions, specifically, early-onset dysfunctions, with faster progression of cardinal PD symptoms and reduced survival ${ }^{60}$.

Therefore, assessing RBD and autonomic dysfunction from PD onset could contribute to patient management with respect to both pharmacological and non-pharmacological treatments. Further, it could allow managing patient expectations, especially in cases of greater severity and more reserved prognosis.

\section{References}

1. Aygun D, Turkel Y, Onar MK, Sunter T. Clinical REM sleep behavior disorder and motor subtypes in Parkinson's disease: a questionnaire-based study. Clin Neurol Neurosurg. 2014 Apr;119:54-8. https://doi.org/10.1016/j.clineuro.2014.01.011

2. Pagano G, De Micco R, Yousaf T, Wilson H, Chandra A, Politis M. REM behavior disorder predicts motor progression and cognitive decline in Parkinson disease. Neurology. 2018 Sep;91(10):e894-e905. https://doi.org/10.1212/ WNL.0000000000006134

3. Baig F, Kelly MJ, Lawton MA, Ruffmann C, Rolinski M, Klein JC, et al. Impulse control disorders in Parkinson and RBD: A longitudinal study of severity. Neurology. 2019 Aug;93(7):e675-e687. https://doi. org/10.1212/WNL.0000000000007942

4. Liu Y, Zhu XY, Zhang XJ, Kuo SH, Ondo WG, Wu YC. Clinical features of Parkinson's disease with and without rapid eye movement sleep behavior disorder. Transl Neurodegener. 2017 Dec;6:35. https://doi. org/10.1186/s40035-017-0105-5

5. Mahajan A, Rosenthal LS, Gamaldo C, Salas RE, Pontone GM, McCoy A, et al. REM sleep behavior and motor findings in Parkinson's disease: a cross-sectional analysis. Tremor Other Hyperkinet Mov (N Y). 2014 Jun;4:245. https://doi.org/10.7916/ D84B2ZDF
6. Frauscher B, Nomura T, Duerr S, Ehrmann L, Gschliesser V, Wenning GK, et al. Investigation of autonomic function in idiopathic REM sleep behavior disorder. J Neurol. 2012 Jun;259(6):1056-61. https:// doi.org/10.1007/s00415-011-6298-0

7. Ferini-Strambi L, Oertel W, Dauvilliers Y, Postuma RB, Marelli S, Iranzo A, et al. Autonomic symptoms in idiopathic REM behavior disorder: A multicentre case-control study. J Neurol. 2014 Jun;261(6):1112-8. https://doi.org/10.1007/s00415-014-7317-8

8. Janković M, Svetel M, Kostić V. Frequency of REM sleep behavior disorders in patients with Parkinson's disease. Vojnosanit Pregl. 2015 May;72(5):442-6. https://doi.org/10.2298/vsp130501006j

9. Munhoz RP, Moro A, Silveira-Moriyama L, Teive HA. Non-motor signs in Parkinson's disease: a review. Arq Neuropsiquiatr. 2015 May;73(5):454-62. https://doi.org/10.1590/0004-282X20150029

10. Högl B, Stefani A. REM sleep behavior disorder (RBD): Update on diagnosis and treatment. Somnologie (Berl). 2017;21(Suppl 1):1-8. https://doi.org/10.1007/s11818-016-0048-6

11. Boeve BF. REM sleep behavior disorder: Updated review of the core features, the REM sleep behavior disorder-neurodegenerative disease association, evolving concepts, controversies, and future directions. Ann N Y Acad Sci. 2010 Jan;1184:15-54. https://doi. org/10.1111/j.1749-6632.2009.05115.x 
12. Fraigne JJ, Torontali ZA, Snow MB, Peever JH. REM sleep at its core circuits, neurotransmitters, and pathophysiology. Front Neurol. 2015 May;6:123. https://doi.org/10.3389/fneur.2015.00123

13. Fantini ML, Ferini-Strambi L, Montplaisir J. Idiopathic REM sleep behavior disorder: Toward a better nosologic definition. Neurology. 2005 Mar;64(5):780-6. https://doi.org/10.1212/01. WNL.0000152878.79429.00

14. Postuma RB, Lanfranchi PA, Blais H, Gagnon JF, Montplaisir JY. Cardiac autonomic dysfunction in idiopathic REM sleep behavior disorder. Mov Disord. 2010 Oct;25(14):2304-10. https://doi. org/10.1002/mds.23347

15. Sorensen GL, Mehlsen J, Jennum P. Reduced sympathetic activity in idiopathic rapid-eye-movement sleep behavior disorder and Parkinson's disease. Auton Neurosci. 2013 Dec;179(1-2):138-41. https://doi.org/10.1016/j.autneu.2013.08.067

16. Lee H, Cho YW, Kim HA. The severity and pattern of autonomic dysfunction in idiopathic rapid eye movement sleep behavior disorder. Mov Disord. 2015 Nov;30(13):1843-8. https://doi. org/10.1002/mds.26416

17. Aguirre-Mardones C, Iranzo A, Vilas D, Serradell M, Gaig C, Santamaria $J$, et al. Prevalence and timeline of nonmotor symptoms in idiopathic rapid eye movement sleep behavior disorder. J Neurol. 2015 Jun;262(6):1568-78. https://doi.org/10.1007/s00415-015-7742-3

18. Bedard MA, Aghourian M, Legault-Denis C, Postuma RB, Soucy JP, Gagnon JF, et al. Brain cholinergic alterations in idiopathic REM sleep behaviour disorder: a PET imaging study with (18) F-FEOBV. Sleep Med. 2019 Jun;58:35-41. https://doi.org/10.1016/j. sleep.2018.12.020

19. Zitser J, During EH, Chiaro G, Miglis MG. Autonomic impairment as a potential biomarker in idiopathic REM-sleep-behavior disorder. Auton Neurosci. 2019 Sep;220:102553. https://doi.org/10.1016/j. autneu.2019.05.005

20. Schenck CH, Boeve BF, Mahowald MW. Delayed emergence of a parkinsonian disorder or dementia in $81 \%$ of older men initially diagnosed with idiopathic rapid eye movement sleep behavior disorder: a 16-year update on a previously reported series. Sleep Med. 2013 Aug;14(8):744-8. https://doi.org/10.1016/j. sleep.2012.10.009

21. Kim YE, Jeon BS. Clinical implication of REM sleep behavior disorder in Parkinson's disease.J Parkinsons Dis. 2014;4(2):237-44. https:// doi.org/10.3233/JPD-130293

22. Zhang X, Sun X, Wang J, Tang L, Xie A. Prevalence of rapid eye movement sleep behavior disorder (RBD) in Parkinson's disease: a meta and meta-regression analysis. Neurol Sci. 2017 Jan;38(1):16370. https://doi.org/10.1007/s10072-016-2744-1

23. Munhoz RP, Teive HA. REM sleep behaviour disorder: how useful is it for the differential diagnosis of parkinsonism? Clin Neurol Neurosurg. 2014 Dec;127:71-4. https://doi.org/10.1016/j. clineuro.2014.09.014

24. Kim YE, Yang HJ, Yun JY, Kim HJ, Lee JY, Jeon BS. REM sleep behavior disorder in Parkinson disease: association with abnormal ocular motor findings. Parkinsonism Relat Disord. 2014 Apr;20(4):444-6. https://doi.org/10.1016/j.parkreldis.2013.12.003

25. Alatriste-Booth $\vee$, Rodríguez-Violante M, Camacho-Ordoñez A, Cervantes-Arriaga A. Prevalence and correlates of sleep disorders in Parkinson's disease: a polysomnographic study. Arq Neuropsiquiatr. 2015 Mar;73(3):241-5. https://doi.org/10.1590/0004-282X20140228

26. Swallow DM, Lawton MA, Grosset KA, Malek N, Smith CR, Bajaj NP, et al. Variation in recent onset parkinson's disease: implications for prodromal detection. J Parkinsons Dis. 2016 Mar;6(2):289-300. https://doi.org/10.3233/JPD-150741

27. Chahine LM, Xie SX, Simuni T, Tran B, Postuma R, Amara A, et al. Longitudinal changes in cognition in early Parkinson's disease patients with REM sleep behavior disorder. Parkinsonism Relat Disord. 2016 Jun;27:102-6. https://doi.org/10.1016/j. parkreldis.2016.03.006
28. Suzuki K, Okuma Y, Uchiyama T, Miyamoto M, Sakakibara R, Shimo Y, et al. Impact of sleep-related symptoms on clinical motor subtypes and disability in Parkinson's disease: a multicentre cross-sectional study. J Neurol Neurosurg Psychiatry. 2017 Nov;88(11):953-9. https:// doi.org/10.1136/jnnp-2017-316136

29. Zhang J, Xu CY, Liu J. Meta-analysis on the prevalence of REM sleep behavior disorder symptoms in Parkinson's disease. BMC Neurol. 2017 Feb;17:23. https://doi.org/10.1186/s12883-017-0795-4

30. Duarte Folle A, Paul KC, Bronstein JM, Keener AM, Ritz B. Clinical progression in Parkinson's disease with features of REM sleep behavior disorder: a population-based longitudinal study. Parkinsonism Relat Disord. 2019 May;62:105-11. https://doi. org/10.1016/j.parkreldis.2019.01.018

31. Postuma RB, Montplaisir J, Lanfranchi P, Blais H, Rompre S, Colombo R, et al. Cardiac autonomic denervation in Parkinson's disease is linked to REM sleep behavior disorder. Mov Disord. 2011 Jul;26(8):1529-33. https://doi.org/10.1002/mds.23677

32. Fantini ML, Macedo L, Zibetti M, Sarchioto M, Vidal T, Pereira B, et al. Increased risk of impulse control symptoms in Parkinson's disease with REM sleep behaviour disorder. J Neurol Neurosurg Psychiatry. 2015 Feb;86(2):174-9. https://doi.org/10.1136/jnnp2014-307904

33. Cui SS, Du JJ, Fu R, Lin YQ, Huang P, He YC, et al. Prevalence and risk factors for depression and anxiety in Chinese patients with Parkinson disease. BMC Geriatr. 2017 Nov;17:270. https://doi. org/10.1186/s12877-017-0666-2

34. Jozwiak N, Postuma RB, Montplaisir J, Latreille V, Panisset M, Chouinard S, et al. REM sleep behavior disorder and cognitive impairment in Parkinson's disease. Sleep. 2017 Aug;40(8):zsx101. https://doi.org/10.1093/sleep/zsx101

35. Kang SH, Yoon IY, Lee SD, Han JW, Kim TH, Kim KW. REM sleep behavior disorder in the Korean elderly population: prevalence and clinical characteristics. Sleep. 2013 Aug;36(8):1147-52. https://doi. org/10.5665/sleep. 2874

36. Kim Y, Kim YE, Park EO, Shin CW, Kim HJ, Jeon B. REM sleep behavior disorder portends poor prognosis in Parkinson's disease: A systematic review. J Clin Neurosci. 2018 Jan;47:6-13. https://doi. org/10.1016/j.jocn.2017.09.019

37. Liu H, Ou R, Wei Q, Hou Y, Cao B, Zhao B, et al. Rapid eye movement behavior disorder in drug-naive patients with Parkinson's disease. J Clin Neurosci. 2019 Jan;59:254-8. https://doi.org/10.1016/j. jocn.2018.07.007

38. Banks SJ, Bayram E, Shan G, LaBelle DR, Bluett B. Non-motor predictors of freezing of gait in Parkinson's disease. Gait Posture. 2019 Feb;68:311-6. https://doi.org/10.1016/j.gaitpost.2018.12.009

39. Bargiotas P, Ntafouli M, Lachenmayer ML, Krack P, Schupbach WMM, Bassetti CLA. Apathy in Parkinson's disease with REM sleep behavior disorder. J Neurol Sci. 2019 Apr;399:194-8. https://doi.org/10.1016/j. jns.2019.02.028

40. Pilotto A, Romagnolo A, Tuazon JA, Vizcarra JA, Marsili L, Zibetti M, et al. Orthostatic hypotension and REM sleep behaviour disorder: impact on clinical outcomes in alpha-synucleinopathies. J Neurol Neurosurg Psychiatry. 2019 Nov;90(11):1257-63. https://doi. org/10.1136/jnnp-2019-320846

41. Braak H, Del Tredici K, Rüb U, de Vos RA, Jansen Steur EN, Braak E. Staging of brain pathology related to sporadic Parkinson's disease. Neurobiol Aging. Mar-Apr 2003;24(2):197-211. https://doi. org/10.1016/s0197-4580(02)00065-9

42. Iranzo A, Fernandez-Arcos A, Tolosa E, Serradell M, Molinuevo JL, Valldeoriola F, et al. Neurodegenerative disorder risk in idiopathic REM sleep behavior disorder: Study in 174 patients. PLoS One. 2014 Feb;9(2):e89741. https://doi.org/10.1371/journal.pone.0089741

43. Beissner F, Meissner K, Bar KJ, Napadow V. The autonomic brain: an activation likelihood estimation meta-analysis for central processing of autonomic function. J Neurosci. 2013 Jun;33(25):10503-11. https://doi.org/10.1523/JNEUROSCI.1103-13.2013 
44. Fenster RJ, Lebois LAM, Ressler KJ, Suh J. Brain circuit dysfunction in post-traumatic stress disorder: from mouse to man. Nat Rev Neurosci. 2018 Sep;19(9):535-51. https://doi.org/10.1038/s41583018-0039-7

45. Miglis MG. Autonomic dysfunction in primary sleep disorders. Sleep Med. 2016 Mar;19:40-9. https://doi.org/10.1016/j.sleep.2015.10.001

46. McDonald C, Winge K, Burn DJ. Lower urinary tract symptoms in Parkinson's disease: Prevalence, aetiology and management. Parkinsonism Relat Disord. 2017 Feb;35:8-16. https://doi. org/10.1016/j.parkreldis.2016.10.024

47. Palma JA, Gomez-Esteban JC, Norcliffe-Kaufmann L, Martinez J, Tijero B, Berganzo K, et al. Orthostatic hypotension in Parkinson disease: how much you fall or how low you go? Mov Disord. 2015 Apr;30(5):639-45. https://doi.org/10.1002/mds.26079

48. Yu QJ, Yu SY, Zuo LJ, Lian TH, Hu Y, Wang RD, et al. Parkinson disease with constipation: clinical features and relevant factors. Sci Rep. 2018 Jan;8(1):567. https://doi.org/10.1038/s41598-017-16790-8

49. Srivanitchapoom P, Pandey S, Hallett M. Drooling in Parkinson's disease: a review. Parkinsonism Relat Disord. 2014 Nov;20(11):1109 18. https://doi.org/10.1016/j.parkreldis.2014.08.013

50. Bronner G, Vodusek DB. Management of sexual dysfunction in Parkinson's disease. Ther Adv Neurol Disord. 2011 Nov;4(6):375-83. https://doi.org/10.1177/1756285611411504

51. Nomura T, Inoue Y, Kagimura T, Nakashima K. Clinical significance of REM sleep behavior disorder in Parkinson's disease. Sleep Med. 2013 Feb;14(2):131-5. https://doi.org/10.1016/j.sleep.2012.10.011

52. Anang JB, Gagnon JF, Bertrand JA, Romenets SR, Latreille V, Panisset $\mathrm{M}$, et al. Predictors of dementia in Parkinson disease: a prospective cohort study. Neurology. 2014 Sep;83(14):1253-60. https://doi. org/10.1212/WNL.0000000000000842
53. Kim JS, Park HE, Oh YS, Lee SH, Park JW, Son BC, et al. Orthostatic hypotension and cardiac sympathetic denervation in Parkinson disease patients with REM sleep behavioral disorder.J Neurol Sci. 2016 Mar 15;362:59-63. https://doi.org/10.1016/j.jns.2016.01.020

54. Jin H, Zhang JR, Shen Y, Liu CF. Clinical significance of REM sleep behavior disorders and other non-motor symptoms of Parkinsonism. Neurosci Bull. 2017 Oct;33(5):576-84. https://doi.org/10.1007/ s12264-017-0164-8

55. Kim JS, Park HE, Park IS, Oh YS, Ryu DW, Song IU, et al. Normal 'heart' in Parkinson's disease: is this a distinct clinical phenotype? Eur J Neurol. 2017 Feb;24(2):349-56. https://doi.org/10.1111/ene.13206

56. Fereshtehnejad SM, Postuma RB. Subtypes of Parkinson's disease: what do they tell us about disease progression? Curr Neurol Neurosci Rep. 2017 Apr;17(4):34. https://doi.org/10.1007/s11910-017-0738-x

57. Al-Qassabi A, Pelletier A, Fereshtehnejad SM, Postuma RB. Autonomic sweat responses in REM sleep behavior disorder and Parkinsonism. J Parkinsons Dis. 2018;8(3):463-8. https://doi. org/10.3233/JPD-181357

58. Kadastik-Eerme L, Rosenthal M, Paju T, Muldmaa M, Taba P. Healthrelated quality of life in Parkinson's disease: a cross-sectional study focusing on non-motor symptoms. Health Qual Life Outcomes. 2015 Jun;13:83. https://doi.org/10.1186/s12955-015-0281-x

59. Mendoza-Velásquez JJ, Flores-Vázquez JF, Barrón-Velázquez E, Sosa-Ortiz AL, Illigens BW, Siepmann T. Autonomic dysfunction in alpha-synucleinopathies. Front Neurol. 2019 Apr;10:363. https://doi. org/10.3389/fneur.2019.00363

60. De Pablo-Fernandez E, Tur C, Revesz T, Lees AJ, Holton JL, Warner TT. Association of autonomic dysfunction with disease progression and survival in Parkinson disease. JAMA Neurol. 2017 Aug;74(8):970-6. https://doi.org/10.1001/jamaneurol.2017.1125 